\title{
A retrospective analytical study of caesarean section in intrauterine foetal death cases in a rural medical college
}

\author{
Kajal Patra $^{1}$, Shibram Chattopadhyay ${ }^{2 *}$, Poulami Samanta ${ }^{2}$, Chandrakanta Mondal ${ }^{1}$
}

\begin{abstract}
${ }^{1}$ Department of Obstetrics and Gynecology, Bankura Sanmilani Medical College, West Bengal, India
${ }^{2}$ Department of Obstetrics and Gynecology, NRSMC, West Bengal, India
\end{abstract}

Received: 18 May 2018

Accepted: 28 May 2018

\section{*Correspondence:}

Dr. Shibram Chattopadhyay,

E-mail: shibramchatt@gmail.com

Copyright: (c) the author(s), publisher and licensee Medip Academy. This is an open-access article distributed under the terms of the Creative Commons Attribution Non-Commercial License, which permits unrestricted non-commercial use, distribution, and reproduction in any medium, provided the original work is properly cited.

\begin{abstract}
Background: Intrauterine fetal death(IUFD) is an unhappy reality, a lamentable incidence for both the family and the caregiver. It is an important indicator of both maternal and perinatal health in a population. The study of fetal death is crucial in promoting actions for maternal and child health. Aim of this study was to determine the incidence, indications and maternal morbidity and maternal mortality associated with caesarean section in patients with IUFD and to establish the place of caesarean section in present day scenario.

Methods: The study was a retrospective analysis of all caesarean section carried out in a case of IUFD in last 5 years (2013-2017). The indications, incidence, maternal morbidity, mortality was studied well in this time period in a rural medical college of West Bengal.

Results: Total 108425 deliveries occurred in the hospital in last 5 years, out of which 31800 were caesarean section. 56 cases were done in case of diagnosed IUFD. There was 2489 number of IUFDs in the given period. The incidence of IUFD was 22.96 per 1000 deliveries. Induction was done in 2489 cases; 56 cases underwent caesarean section $(2.25 \%)$ and rest was delivered vaginally.

Conclusions: Early diagnosis, early referral and proper antenatal checkup can reduce the chances of IUFD and number of caesarean deliveries in IUFD. The role of cesarean deliveries in previous caesarean deliveries having IUFDs has been emphasized.
\end{abstract}

Keywords: Caesarean deliveries, Intrauterine fetal death, Maternal Mortality

\section{INTRODUCTION}

Foetal death means death prior to complete expulsion or extraction from the mother of a product of human conception irrespective of the duration of pregnancy and which is not an induced termination of pregnancy. ${ }^{1}$

Intrauterine fetal death(IUFD) at any gestational age is a major but often overlooked health issue. It is estimated that more than 7.6 million perinatal deaths occur worldwide each year, of which $57 \%$ are of fetal deaths. ${ }^{2}$ WHO recommends the inclusion of all infants born dead and weighing $1000 \mathrm{~g}$ or more (if birth weight is available), or after 28 completed weeks of gestation, or attainment of $35 \mathrm{~cm}$ crown-heel length. ${ }^{3}$

RCOG green top guideline No. 55 recommends that labour and birth should take into account the mother's preferences and her medical condition and previous intrapartum history. Vaginal birth is the recommended mode of delivery for most women, but caesarean birth would need to be considered with some. ${ }^{4}$

The factors related to the indication of caesarean section in pregnant women with dead fetus are poorly studied. The study of fetal death is crucial in promoting actions 
for maternal and child health and since the recommended mode of delivery is vaginal, aim of this study was to study the main factors associated with caesarean section indication in pregnant women with a dead fetus.

\section{METHODS}

It was a cross sectional, retrospective case review of all patients with IUFD between 1st January 2013 and 31st December 2017, in Bankura Sammilani Medical College, West Bengal. We included those cases with fetal death after 20 weeks of pregnancy or fetal birth weight more than $500 \mathrm{gm}$ when period of gestation was not known.

Obstetric factors included were antenatal visits (coded as yes or no), mode of delivery and the presence of risk factors like pre-labour rupture of membranes, preterm labour, hypertensive pregnancy disorders, antepartum haemorrhage, cephalopelvic disproportion, prolonged or obstructed labour and severe anaemia. Fetuses with congenital anomalies are excluded from this study.

\section{RESULTS}

Total deliveries during the study period were 108425 out of which 76625 were vaginal deliveries.

There were 2489 cases of IUFD reported (22.96/1000 deliveries), out of 2489 cases, 56 patients had undergone caesarean deliveries $(2.25 \%)$ and the rest 2,433 IUFD cases were delivered vaginally $(97.75 \%)$.

Table 1: Patient details such as age, parity and period of gestation.

\begin{tabular}{|c|c|c|c|}
\hline \multicolumn{2}{|c|}{ Patient detail } & $\begin{array}{l}\text { Vaginal } \\
\text { deliveries } \\
(n=2433)(\%)\end{array}$ & $\begin{array}{l}\text { Caesarean } \\
\text { deliveries } \\
(\mathrm{n}=56) \\
(\%)\end{array}$ \\
\hline \multirow{4}{*}{ Age (years) } & $<20$ & $1180(48.5)$ & $12(21.43)$ \\
\hline & $20-29$ & $828(34.03)$ & $38(67.86)$ \\
\hline & $30-34$ & $280(11.51)$ & $05(08.93)$ \\
\hline & $\geq 35$ & $145(05.96)$ & $01(01.79)$ \\
\hline \multirow{4}{*}{ Parity } & $\begin{array}{l}\text { Primi } \\
\text { gravida }\end{array}$ & $1238(50.85)$ & $02(3.57)$ \\
\hline & $\begin{array}{l}\text { Second } \\
\text { gravida }\end{array}$ & $640(26.3)$ & $18(32.14)$ \\
\hline & $\begin{array}{l}\text { Third } \\
\text { gravida }\end{array}$ & 418 (17.18) & $24(42.86)$ \\
\hline & $\begin{array}{l}\text { Fourth } \\
\text { gravida } \\
\text { or more }\end{array}$ & $137(5.63)$ & $12(21.43)$ \\
\hline \multirow{3}{*}{$\begin{array}{l}\text { Period of } \\
\text { gestation } \\
\text { (weeks) }\end{array}$} & $20-28$ & 2035 (83.64) & $04(7.14)$ \\
\hline & $29-36$ & $280(11.50)$ & $11(19.64)$ \\
\hline & $\geq 37$ & $128(52.60)$ & $41(73.21)$ \\
\hline
\end{tabular}

Patient details such as age, parity and period of gestation are discussed in Table 1. Caesarean deliveries in patients with IUFD were mainly seen in 20-29 years $(67.86 \%)$ aged patients and third gravidas $(42.86 \%)$ having more than 37 weeks period of gestation $(73.21 \%)$.

After much multivariate analysis, it was seen that certain factors were significantly associated with caesarean deliveries as shown in Table 2. From the above table it's evident that the most common cause of LSCS in IUFD was previous caesarean section along with gestational hypertension and obstructed labour.

Table 2: Factors associated with caesarean deliveries.

\begin{tabular}{|l|l|}
\hline Indications of LSCS & No. $(n=56)(\%)$ \\
\hline Previous 1 LSCS & $38(67.86)$ \\
\hline Gestational hypertension & $06(10.71)$ \\
\hline Obstructed labor & $04(07.14)$ \\
\hline APH & $03(05.36)$ \\
\hline Previous 2 LSCS & $02(03.57)$ \\
\hline Multifetal gestation & $02(3.57)$ \\
\hline Failed induction & $01(01.79)$ \\
\hline
\end{tabular}

Though misoprostol is the method of choice for induction, its use is contraindicated due to the increased risk of uterine rupture in the presence of previous LSCS. Though PIH is not an absolute indication for LSCS, but its definitive treatment is termination of pregnancy.

Various risk factors have been seen associated with the caesarean deliveries for IUFD pregnancies as shown in Table 3. From the above table it is seen that in maximum cases the cause of IUFD is not known. It is mostly seen in un-booked cases. The second most common cause was gestational hypertension. The third cause is due to labour complications as many cases are referred to our tertiary centre in the late stage of labour with complications.

Table 3: Various risk factors associated with the caesarean deliveries for IUFD.

\begin{tabular}{|ll|l|}
\hline Maternal risk factors & No of cases & \% of cases \\
\hline Unknown cause & 36 & 64.29 \\
\hline Gestational Hypertension & 06 & 10.71 \\
\hline Labour complications & 05 & 8.93 \\
\hline Anaemia & 04 & 7.14 \\
\hline Placental cause & 03 & 5.36 \\
\hline Medical disorders & 02 & 3.57 \\
\hline
\end{tabular}

\section{DISCUSSION}

The attempt of vaginal delivery in previous caesarean section is recommended when the patient has only one previous caesarean and there is possibility of performing vaginal delivery, or maternal condition are favourable..$^{5,6}$ Specifically in patients with fetal death, which often have unfavorable cervix, induction of labour becomes an alternative. $^{6}$

Currently, misoprostol is the method of choice for induction, but its use is contraindicated due to increased 
risk of uterine rupture in the presence of previous caesarean. The problems that can be related to induction drug therapy are increase of hemorrhagic complication risks, including Placental abruption, uterine rupture, coagulopathy, post-partum hemorrhage, and puerperal hysterectomy. ${ }^{7}$ However, it should not be forgotten that induction of labour may not always be successful. Additionally, such patients should be explained the risks and benefits of all treatment modalities, and free informed and written consent should be taken of the patient and her relatives. This is because all kinds of treatment have some risks to maternal safety, especially when there is an intrauterine fetal loss. ${ }^{8}$

For example, thrombogenic substances produced in the placental tissue that enter the maternal circulation increase the risk of disseminated intravascular coagulation. ${ }^{9}$ This results in guarded prognosis in those patients managed by observation. Also, in expectant management, the unpredictable time during which the pregnant patient has to remain with the dead foetus in the uterus can trigger psychological instabilities in the patient. ${ }^{10}$

Caesarean sections have been often performed in patients with previous caesarean for lack of consensus of the best approach in such situations. ${ }^{11}$ Hypertensive disorders are not an absolute indication for caesarean section, but their definitive treatment is the termination of pregnancy. ${ }^{12}$ In the study by Sampaio AG et al, the major indication for the caesarean was placental abruption (49.3\%) and included both antepartum and intrapartum fetal deaths which explained the higher caesarean rate. ${ }^{13}$

\section{CONCLUSION}

In this study the rate of caesarean deliveries in IUFD cases was $2.25 \%$ done in difficult cases keeping maternal safety in mind. The recommended mode of delivery in case of IUFD is vaginal either spontaneous or by induction with misoprostol. But in previous caesarean deliveries cases due to high chance of rupture uterus, to save life of the mother caesarean is done in maximum cases. In cases of problems in progress of labour or due to placental causes, caesarean delivery is done.

Caesarean delivery is done in PIH if induction fails aswel as in cases of severe PIH in order to terminate the pregnancy. Early diagnosis, early referral and proper antenatal checkup can reduce the chances of IUFD and number of caesarean deliveries in IUFD.

Funding: No funding sources Conflict of interest: None declared

Ethical approval: The study was approved by the Institutional Ethics Committee

\section{REFERENCES}

1. Kowaleski J. State definitions and reporting requirements for live births, fetal deaths, and induced terminations of pregnancy (1997 revision). Hyattsville, Maryland: National Center for Health Statistics.1997. Available http://www.cdc.gov/nchs/data/misc/itop97.pdf.

2. MacDorman MF, Kirmeyer S, Wilson EC. National vital statistics reports. National Vital Statistics Reports. 2010 Mar 3;58(11).

3. WHO: Recommended definition, terminology and format for statistical tables related to the perinatal period and use of new certificate for case of perinatal death. Actaobstet Gyneol Scand. 1997;56(3):247-53.

4. Green-top Guideline No. 55. Late intrauterine fetal death and stillbirth, Royal College of Obstetricians and Gynaecologists. 2010;1-33.

5. National Institute for Clinical Excellence(NICE); National Collaborating Centre for Women's and Children's Health. Caesarean section. London (UK), 2004.

6. National Institute for Health and Clinical Excellence; Clinical guideline no. 70. Induction of labour. London. 2008.

7. Gómez P de LR, Wing D, Fiala C. Misoprostol for intrauterine fetal death. Int $\mathrm{J}$ Gynaecol Obstet. 2007;99(2):S190-3.

8. Nascimento MI, Cunha AD, Oliveira SR. Clinical management of the induction of labor in intrauterine fetal death: evaluation of incidence of cesarean section and related conditions. Revista Brasileira de Epidemiologia. 2014;17:203-16.

9. Papp Z. Fetal Demise. In: World Association of Perinatal Medicine (WAPM), Matres Mundi International. Recommendations and guidelines for perinatal medicine. Disponível em: http://www.wapm.info/Portals/0/recommendations_peri natal.pdf.

10. Brazil. Ministry of Health. Secretariat of Health Care. Department of Strategic Programmatic Actions. High risk pregnancy: technical manual. Brazil. $5^{\text {th }}$ edition. Brasília: Publisher of the Ministry of Health. 2010:1019.

11. Dodd JM, Crowther CA; Elective repeat caeserian section versus induction of labour for woman with previous caeserian birth. Cochrane Database Syst Rev. 2006;4:CD004906.

12. Alanis MC, Robinson CJ, Hulsey TC, Ebeling M, Johnson DD; Early onset severe prevere preeclampsia: induction of labour versus elective caesarean delivery and neonatal outcome. Am J Obstet Gynecol. 2008;199(3):262.el6.

13. Sampaio AG Rolland ASR; Indications of caeserian section in stillbirth. Rev Bras Gynecol Obstet. 2010;32(G):169-75.

Cite this article as: Patra K, Chattopadhyay S, Samanta P, Mondal C. A retrospective analytical study of caesarean section in intrauterine foetal death cases in a rural medical college. Int J Reprod Contracept Obstet Gynecol 2018;7:2583-5. 